GENDERED PARADOXES 



\section{GENDERED PARADOXES}

WOMEN'S MOVEMENTS, STATE RESTRUCTURING, AND GLOBAL DEVELOPMENT IN ECUADOR

\section{AMY LIND}

The Pennsylvania State University Press

University Park, Pennsylvania 
Library of Congress Cataloging-in-Publication Data

Lind, Amy.

Gendered paradoxes : women's movements, state restructuring, and global development in Ecuador / Amy Lind.

p. $\quad \mathrm{cm}$.

Includes bibliographical references and index.

ISBN o-271-02544-1 (alk. paper)

1. Women in development-Ecuador. 2. Women in politics-Ecuador.

3. Feminism-Ecuador. 4. Indian women-Ecuador. 5. Poor women-Ecuador.

6. Structural adjustment (Economic policy)-Ecuador.

7. Ecuador-Social policy.

8. Ecuador-Politics and government-1984- .

I. Title.

$$
\begin{gathered}
\mathrm{HQ}_{1240.5} \cdot \mathrm{E}_{2} \mathrm{~L}_{5} 6 \\
\text { 305.42' } 09005 \\
206-\mathrm{dc} 22 \\
2004015106
\end{gathered}
$$

Copyright (C) 2005 The Pennsylvania State University

All rights reserved

Printed in the United States of America

Published by The Pennsylvania State University Press,

University Park, PA 16802-1003

The Pennsylvania State University Press is a member of the Association of American University Presses.

It is the policy of The Pennsylvania State University Press to use acid-free paper.

This book is printed on Natures Natural, containing $50 \%$ post-consumer waste, and meets the minimum requirements of American National Standard for Information Sciences - Permanence of Paper for Printed Library Material, ANSI Z39.48-1992. 
IN MEMORY OF MY GRANDMOTHERS,

Virginia Conger Kelsey

(1913-1982)

Marie Childers Lind

(1911-2000)

TO THE CONGER WOMEN 
